\title{
CEGAH KENAKALAN REMAJA MELALUI PENDIDIKAN KARAKTER
}

\author{
Oleh \\ I Gede Agung Jaya Suryawan \\ Fakultas pada Dharma Acarya IHDN Denpasar
}

\begin{abstract}
Adolescents as the future generation should have the character to be proud of and be a role model to the next generation. However, this time, there are not a few Indonesian adolescent learners do negative things, such as skipping school , involved in brawls, drugs, and sexual harassment. Besides harming themselves such misbehaviors are also harmful to society. All parties, namely families, schools and the community, must work together to find solutions for it. One of the things that can be done is to provide character education in the family and schools that teach children to make decisions wisely and practise it in their daily lives so that they can contribute positively to their environment.
\end{abstract}

Keywords : juvenile delinquency, character education

\section{PENDAHULUAN}

Remaja atau pelajar adalah generasi penerus bangsa, oleh karena itu kaum remaja semestinya mendapatkan pendidikan dengan baik sehingga memiliki kemampuan untuk melanjutkan cita - cita luhur bangsa serta dapat bersaing dengan negara maju. Pendidikan awal dimulai dari pendidikan dalam keluarga oleh orang tua dan dilanjutkan dengan pendidikan formal di lembaga pendidikan yang diberikan oleh tenaga pendidik profesional. Pendidikan yang berhasil adalah pendidikan yang bisa merubah sikap, perilaku, emosi dan pengetahuan peserta didiknya ke arah yang lebih baik. Namun saat ini masih banyak kita temukan para remaja yang berstatus pelajar melakukan pelanggaran norma baik disekolah maupun di masyarakat. Sebagian dari mereka ada yang sampai melakukan perbuatan yang meresahkan masyarakat. Semua ulah remaja ini dikenal dengan sebutan kenakalan remaja.
Seiring perkembangan teknologi dan era globalisasi, kini kenakalan remaja tidak hanya terjadi di kota-kota besar tetapi juga di pedesaan. Menurut Willis (2005:87), bahwa kenakalan remaja bukanlah hal baru. Masalah ini sudah ada sejak berabad-abad yang lampau. Kenakalan remaja pada setiap generasi berbeda karena pengaruh lingkungan kebudayaan dan sikap mental masyarakat pada masa itu. Saat ini kenakalan remaja mulai dari kasus bolos sekolah, tawuran antar pelajar, merokok dan penggunaan obat terlarang, pencurian, pelecehan seksual hingga kasus pembunuhan. Di usia mereka yang seharusnya disibukkan dengan jadwal sekolah dan ektrakulikuler tetapi beberapa oknum pelajar malah menyibukkan diri dengan kegiatan negatif yang tidak saja merugikan diri sendiri tetapi juga orang banyak. Masalah kenakalan remaja, khususnya remaja usia sekolah atau remaja yang sedang duduk di bangku sekolah bukan saja meresahkan orang tua dan masyarakat, 
namun juga meresahkan para guru di sekolah. Kenakalan siswa bukan saja hanya sekedar masalah orang tua dan masyarakat semata. Namun juga merupakan masalah bagi sekolah, karena sekolah sebagai lembaga pendidikan formal dianggap yang paling bertanggung jawab terhadap hasil pendidikan termasuk di dalamnya karakter seorang anak (siswa).

Jika diamati amanat Undang-undang Nomor 20 Tahun 2003 tentang Sistem Pendidikan Nasional lembaga pendidikan (sekolah) memang merupakan wahana bagi pendidikan karakter. Pendidikan karakter hanya mungkin terwujud, jika setiap pendidikan dan tenaga kependidikan di lembaga (sekolah) tersebut menyadari pentingnya pendidikan karakter dalam mencapai tujuan utuh pendidikan. Tanpa kesadaran itu, pendidikan karakter hanya akan tersampaikan sebagai pengetahuan, yang tidak menyentuh nurani siswa. Dengan tidak tersentuhnya nurani atau moral siswa secara baik, tentu saja memungkinkan munculnya sikap dan perilaku yang tidak diinginkan.

Menurut Subagio (2007:15), ada beberapa alasan yang menyebabkan anak (siswa) mengeluh mengenai sekolahnya. Banyak keluhan mengenai sekolah itu mencerminkan perjuangan yang normal pada masa anak-anak. Berikut ini ada beberapa sebab mengapa anak (siswa) mengeluh mengenai sekolah, karena anak (siswa) mengalami kesulitan dalam membina hubungan baik dengan guru mata pelajaran, aturan sekolah, atau perlakuan yang tidak adil. Seperti dikemukakan Willis (2005:114), bahwa kadang-kadang sekolah juga penyebab dari timbulnya kenakalan remaja. Hal ini mungkin bersumber dari guru, fasilitas pendidikan, norma-norma tingkah laku. Kekompakan guru dan suasana interaksi antara guru dan murid perlu menjadi perhatian serius.

Kenakalan remaja sangat banyak yang mengarah ke tindakan kriminal remaja. Hal ini tentunya tidak bisa dipandang sebelah mata, namun sudah menjadi tugas kita semua untuk ikut peduli dan mencari solusi agar kenakalan para remaja ini dapat ditanggulangi dengan baik dan dapat merubah pemikiran para remaja agar memiliki rasa tanggung jawab kepada diri sendiri, keluarga dan bangsa. Tanggung jawab ini tidak dapat diserahkan kepada pihak sekolah karena mereka berstatus pelajar, melainkan diperlukan kerjasama yang baik dari berbagai pihak seperti kepolisian, sekolah, lembaga swadaya masyarakat dan keluarga. Salah satu solusi yang bisa dilakukan adalah penanaman pendidikan karakter remaja secara dini, baik di lingkungan keluarga, sekolah maupun di masyarakat.

Berdasarkan pengertian dari pendidikan karakter menurut Megawangi 2004 (dalam Majid 2011 : 5), yaitu sebuah usaha untuk mendidik anak-anak agar dapat mengambil keputusan dengan bijak dan mempraktikanya dalam kehidupan sehari hari sehingga mereka dapat memberikan kontribusi yang positif kepada lingkunganya. Tujuan pendidikan karakter yaitu membentuk kepribadian manusia serta menciptakan masyarakat dan warga negara yang baik.

\section{PEMBAHASAN \\ 1. Kenakalan Remaja}

Remaja adalah tahapan kehidupan yang dilalui oleh setiap manusia dalam proses perkembangan sejak lahir sampai pada masa peralihan, dari masa kanak - kanak menuju masa dewasa. Perkembangan emosi pada masa remaja ditandai dengan sifat emosional yang meledak - ledak dan sulit untuk dikendalikan. Hal ini disebabkan adanya konflik peran yang sedang dialami remaja. Jika seseorang remaja tidak berhasil mengatasi situasi ini, maka remaja akan terperangkap masuk dalam hal negatif (BKKBN, 2010). Pada umumnyaremaja memiliki rasa in-gin tahu yang tinggi (high curiousity). Remaja cenderung ingin berpetualang menjelajah sega-la sesuatu dan mencoba segala sesuatu 
yang be-lum pernah dialaminya. Selain didorong juga oleh keinginan menjadi seperti orang dewasa menyebabkan remaja ingin mencoba melaku-kan apa yang sering dilakukan orang dewasa dan melakukan apa yang tidak diperbolehkan oleh orang tuanya (Azwar A, 2000). Hal inilah yang menyebabkan banyak kaum remaja yang melakukan perbuatan yang menyimpang dari aturan yang dikenal dengan kenakalan remaja.

Ada berbagai pengertian kenakalan remaja menurut pandangan berbagai ahli. Kenakalan remaja ditinjau dari sudut etimologis berasal dari kata juvenile delinquency (bahasa Latin). Juvenile berasal dari bahasa Latin juvenilis, artinya anak-anak, anak muda. Sedangkan delinquency berasal dari bahasa Latin delinquere, yang berarti terabaikan, mengabaikan yang kemudian artinya diperluas menjadi jahat, asosial, kriminal, pelanggar aturan, pembuat ribut, pengacau, peneror, tidak dapat dipebaiki lagi, durjana, dursila, dan lainlain. Dari jabaran pengertian secara etimologis maka yang dimaksud dengan juvenile delinquent adalah kejahatan anak. Namun pengertian tersebut dapat diinterpretasikan berdampak negatif secara psikologis terhadap anak yang menjadi pelakunya, sehingga pengertian secara etimologis tersebut telah mengalami pergeseran akan tetapi hanya menyangkut aktivitasnya yaitu nilai kejahatan (delinquent) menjadi kenakalan.

Pandangan lain tentang juvenile delinquent dikatakan oleh Sudarsono (1991:86) bahwa suatu perbuatan tergolong kenakalan remaja, jika perbuatan tersebut bersifat melawan hukum, anti sosial, anti susila, dan melanggar norma norma agama yang dilakukan oleh objek yang masih berusia remaja yang menurut sebagian psikolog umur 11-21 tahun, maka perbuatan tersebut cukup alasan untuk disebut kenakalan remaja (juvenile delinquency). Sementara Asiyah (1996:24) menyimpulkan bahwa kenakalan remaja adalah perbuatan anak-anak yang melanggar norma- norma baik norma sosial, norma hukum, norma kelompok, mengganggu ketenteraman masyarakat sehingga yang berwajib mengambil suatu tindakan pengasingan. Kenakalan tersebut dilakukan oleh remaja atau anak dibawah usia 21 tahun.

Dari berbagai pengertian tersebut maka dapat disimpulkan bahwa kenakalan remaja (siswa) adalah tindak perbuatan yang dilakukan siswa di lingkungannya baik lingkungan keluarga, sekolah maupun masyarakat dan perbuatan tersebut bersifat melawan hukum, anti sosial, dan melanggar norma - norma agama.

Kenakalan remaja menurut WHO (dalam Susanti, 2007:43) dapat berupa hal sebagai berikut: pelanggaran hukum atau aturan, kebiasaan membolos, bergabung dengan orang yang diketahui sebagai pencuri, orang-orang amoral atau jahat, anak-anak yang tidak dapat dibantu, perilaku diluar kontrol orang tua,tumbuh di dalam pengangguran atau kenakalan, melukai diri sendiri atau orang lain, melakukan tindakan tidak senonoh, pergi dari rumah tanpa ijin orang tua,kebiasaan menggunakan bahasa atau kata-kata kotor, cabul atau vulgar,berkunjung ke rumah-rumah bordil, kebiasaan ngluyur, melompat kereta atau mobil, perilaku amoral, merokok, menggunakan zat adiktif, perilaku tidak aturan, meminta-minta, meminum minuman keras, tidak teraturan seksual.

Kenakalan remaja menurut Gunarsa (1988:54) dikatakan disebabkan oleh dua faktor yaitu faktor diri sendiri (umur, jenis kelamin, kepribadian, kedudukan dalam keluarga, intelegensu, hormon, dan emosi atau kejiwaan) dan faktor lingkungan (keluarga, sekolah, masyarakat, danmedia masa).

\section{Pendidikan Karakter}

Karakter merupakan pondasi dalam segala hal. Beberapa pengertian karakter menurut para ahli, diantaranya 1) Suyanto (2009), mendefinisikan karakter sebagai cara berpikir 
dan berperilaku yang menjadi ciri khas tiap individu untuk hidup dan bekerja sama, baik dalam lingkup keluarga, masyarakat, bangsa, maupun negara, 2) Karakter adalah ciri khas yang dimiliki oleh suatu benda atau individu. Ciri khas tersebut adalah asli dan mengakar pada kepribadian benda atau individu tersebut, serta merupakan "mesin" yang mendorong bagaimana seorang bertindak, bersikap, berucap, dan merespon sesuatu (Kertajaya, 2010).

Sedangkan pendidikan karakter adalah salah satu pendidikan yang bisa meningkatkan kemampuan peserta didik dalam berbagai bidangnya. Dikatakan pula bahwa pendidikan karakter adalah sebuah usaha untuk mendidik anak-anak agar dapat mengambil keputusan dengan bijak dan mempraktikkannya dalam kehidupan sehari-hari, sehingga mereka dapat memberikan kontribusi yang positif kepada lingkungannya (Megawangi dalam Kesuma, dkk., 2011: 7). Pendidikan Karakter Menurut Lickona: menyatakan bahwa pendidikan karakter adalah suatu usaha yang disengaja untuk membantu seseorang sehingga ia dapat memahami, memperhatikan, dan melakukan nilai-nilai etika yang inti. Dalam pendidikan karakter, terdapat nilai-nilai yang dikembangkan melalui pendidikan budaya dan karakter, karakter bangsa diidentifikasi dari sumbersumber inti. Sumber dimaksud adalah Agama, Pancasila, budaya dan Tujuan Pendidikan Nasional.

\section{a. Pendidikan Karakter Dalam Keluarga}

Kehidupan seorang anak dimulai semenjak berada dalam kandungan ibunya kemudian terlahir dan dibesarkan di lingkungan keluarga. Setiap anak terlahir dengan karakter yang berbeda beda namun dalam perkembangannya sangat dipengaruhi oleh lingkungan keluarga dan lingkungan tempat tinggalnya serta lingkungan sekolahnya. Orang tua harus mengetahui kearakter setiap anaknya sehingga dapat memberikan perlakuan yang sesuai dengan karakternya. Pentingnya pendidikan karakter pada usia dini yang diberikan oleh orang tua dapat menumbuh kembangkan anak menjadi cerdas secara intelektual, spiritual, dan emosial yang lebih insan dan berkarakter. Golden age yaitu sebuah masa keemasan usia seorang anak dimana periode masa keemasan ini hanya datang satu kali saja seumur hidup yang tidak dapat diulang lagi. Para orang tua memiliki tanggung jawab terhadap tumbuh kembang anak baik secara fisik, emosional, spiritual, maupun sosial.

Orang tua memang selayaknya tahu kapan saatnya anak-anak harus dilarang dan kapan anak menadapatkan kebebasan. Orang tua harus mengetahui banyaknya orang tua yang sangat sayang terhadap anak-anaknya, tetapi praktek kesayangannya bertentangan dengan hakekat azas pendidikan. Semua ini terjadi antara lain disebabkan orang tua terlalu awam dalam dunia pendidikan, sehingga mereka tidak mengerti perkembangan kejiwaan anakanaknya dari fase ke fase. Orang tua sebaiknya membiarkan anak-anaknya untuk dapat berkembang dalam menemukan jati dirinya namun tetap melakaukan pemantauan (Malak, 2004 : 19)

Para Orang tua senantiasa meluangkan waktunya untuk memperhatikan perkembangan anak. Setiap perubahan baik pisik maupun psikis pada anak sebaiknya orang tua dapat menjelaskan kenapa hal tersebut terjadi. Komunikasi yang baik harus terjalin antara anak dan orang tua sehingga bila si anak mengalami kesulitan atau ada masalah mereka bisa bercerita dan mencari solusi dari orang tuanya. Sebaliknya bila komunikasi tidak terjalin baik maka anak akan melampiaskan kemarahan atau rasa frustasinya dengan melakukan hal yang negatif.

Selain hal tersebut para orang tua juga memiliki kewajiban untuk menanamkan nilainilai agama dan budi pekerti yang baik sejak anak lahir hingga anak tersebut dewasa. Mereka sebaiknya diberikan pemahaman keTuhanan dan diajarkan tentang kehidupan 
adalah tidak hanya saat hidup saja tetapi ada juga setelah kematian. Selain dilakukan secara lisan, orang tua juga harus memberikan contoh atau keteladanan dalam bertutur dan berperilaku yang baik dalam kehidupan seharihari dalam berinteraksi dengan orang lain. Hal ini bertujuan agar pemahaman anak lebih melekat.

Orang tua jangan memaksakan kehendak terhadap anak, karena anak akan menjadi pribadi yang memberontak, karena anak masih dalam proses pertumbuhan dan perkembangan. Orang tua hendaknya memantau pergaulan anak-anaknya, namun bukan berarti mengekang mereka. Tidak semua pergaulan baik untuk anak namun juga ada yang membawa dampak negatif. Anak-anak perlu diingatkan dan juga dinasehati tentang pergaulan agar lebih waspada dalam memiih teman. Orang tua sebaikya menghindarkan anak dari kebiasaan-kebiasaan yang kurang baik. Pada dasarnya hubungan orang tua dengan anak terganung dari orang tuanya. Sikap orang tua sangat menentukan hubngan suatu keluarga. Sikap orang tua tidak hanya berpengaruh terhadap keluarga melainkan pada perilaku anak. Anak perlu diberi pengawasan agar tidak berbuat menyimpang. Di dalam kehidupan keluargapun harus ada interaksi dan kerjasama agar terciptanya kerukunan dalam masing-masing anggota keluarga sehingga terjalin suatu hubungan yang baik. Anak dan orang tua sebaiknya saling mengerti satu sama lain agar terciptanya hubungan yang harmonis dan baik. Demikian agar anak dapat berperilaku baik sesuai dengan perkembangannya sesuai tingkatannya (Husaini, 2013).

\section{b. Pendidikan Karakter Di Sekolah}

Seperti yang kita ketahui bahwa pendidikan dilakukan tidak hanya untuk memberikan anak ilmu pengetahuan tetapi juga untuk menanamkan dan mensosialisasikan nilainilai dan norma-norma yang ada dalam masyarakat agar ia bisa tumbuh dengan memahami nilai dan norma tersebut dan bisa membaur dalam kehidupan bermasyarakat di kemudian hari. Guru merupakan salah satu faktor penentu dalam keberhasilan pelaksanaan pendidikan karakter di sekolah sehingga diperlukan pemahaman yang baik tentang konsep dari pendidikan karakter.

Seperti yang kita ketahui saat ini para guru masih belum sepenuhnya mengembangkan nilainilai karakter peserta didiknya dalam proses pembelajaran dikelas. Sebagian besar guru beranggapan hanya guru mata pelajaran kewarganegaraan dan agama lah yang memiliki tugas tersebut, padahal seharusnya tanggung jawab ini harus dilaksanakan oleh semua guru. Salah satu strategi mengembangkan pendidikan karakter adalah dengan mengintegrasikan nilainilai karakter bangsa pada setiap mata pelajaran sehingga menghasilkan peserta didik yang konsisten dalam perilaku berkarakter di kehidupannya sehari-hari.Pendidikan karakter dapat dikembangkan dengan beberapa cara yaitu dengan pengintegrasian ke dalam mata pelajaran, pembiasaan, pengkondisian, serta pencontohan/teladan sehingga guru harus berupaya untuk melaksanakan strategi-strategi tersebut dengan maksimal di sekolah (Antara news, 2011)

Pendidikan karakter merupakan salah satu upaya yang harus dilaksanakan sekolah untuk membina moral serta akhlak yang sesuai dengan norma dan nilai-nilai dari Tuhan YME. Pendidikan karakter dilaksanakan sebagai bentuk penempaan terhadap sikap peserta didik sebagai anak bangsa sehingga dengan adanya pembinaan karakter bagi peserta didik akan mampu membentuk bangsa yang tangguh serta mampu berkompetisi sehat di era globalisasi. Nilai karakter yang mulai dikembangkan melalui pembiasaan sikap di sekolah yaitu: 1) Siswa berdo'a sebelum dan sesudah belajar, memberikan salam, serta meminta izin keluar/masuk kelas sebagai implementasi nilai religius. 2) Siswa melaksanakan tugas piket kebersihan kelas, 
menanami/merawat tanaman yang ada di sekitar kelas, serta melaksanakan kegiatan kerja bakti setiap hari jum' at sebagai perwujudan nilai peduli lingkungan. 3) Siswa melaksanakan upacara bendera setiap hari senin, serta menyanyi-kan lagu nasional sebagai implementasi nilai semangat kebangsaan.

Selain pembiasaan sikap, sebaiknya para guru mulai mengintegrasikan nilai pendidikan karakter dalam kegiatan pembelajaran di kelas yaitu dengan menggunakan metode pembelajaran diskusi sebagai nilai komunikatif/ bersahabat. Selain itu, ada juga pemberian tugas yang kepada peserta didik ketika guru tidak masuk memberikan pembelajaran di kelas sehingga siswa sudah terbiasa untuk belajar di kelas meski tidak ada guru, hal tersebut mencerminkan nilai mandiri. Kegiatan spontan juga sebaiknya dilaksanakan di sekolah oleh guru dan peserta didik yaitu guru langsung menegur peserta didik saat melakukan kesalahan, dan antara sesama peserta didik juga diajarkan untuk saling menegur jika ada teman lainnnya yang melakukan perbuatan tidak terpuji. Hal ini bertujuan agar anak terbiasa saling mengingatkan bila menemukan temannya ada yang melakukan perbuatan yang salah.

Nilai karakter yang dibutuhkan di sekolah yaitu nilai karakter cinta damai dan toleransi. Para guru sebaiknya selalu menanamkan sikap persahabatan dan menyayangi antar warga sekolah. Guru juga harus memberikan contoh agar dapat ditiru oleh anak didiknya. Komunikasi yang baik harus terjalin antara guru dan peserta didik sehingga mereka merasa aman dan nyaman untuk datang dan belajar disekolah. Hal ini juga dapat mempengaruhi perkembangan mental dan prestasi anak.

Peduli terhadap lingkungan juga merupakan pendidikan karakter yang harus dikembangkan di sekolah. Anak diajarkan untuk mencintai lingkungan tempat tinggalnya dengan mulai melakukan hal kecil seperti membuang sampah pada tempatnya. Sekolah seharusnya menyediakan tempat sampah organik dan non organik sehingga anak dapat memilah sampahnya, agar mereka memahami bahwa ada sampah yang berguna dan sampah yang dapat merusak lingkungan. Hal ini melatih rasa memiliki dan kepedulian anak.

Melatih kedisiplinan anak di sekolah dapat dilakukan dengan membiasakan mereka agar datang tepat waktu dan mengerjakan tugas yang diberikan oleh guru pendidikan dikelas sekolah juga sebaiknya mengembangkan kegiatan ektrakulikuler yang wajib dan non wajib sehingga anak terbiasa membagi waktu untuk kegiatan sekolah. Semua hal tersebut sebaiknya dilaksanakan oleh para guru secara kompak dan berkesinambungan baik di tingkat sekolah dasar, menengah pertama, menengah atas maupun di bangku kuliah. Ini bertujuan agar anak selalu terbiasa berhadapan dengan hal yang positif sehingga dalam kehidupannya mereka selalu berbuat yang positif pula (Prasetyo A, 2010).

\section{SIMPULAN}

Pendidikan karakter merupakan pendidikan yang harus diberikan kepada anak sejak usia dini. Pendidikan ini dapat diberikan mulai di lingkungan keluarga, sekolah, dan masyarakat. Para orang tua memiliki kewajiban untuk memenuhi kebutuhan anak baik fisik, emosional, spiritual, dan sosial. Mereka harus bisa menjadi suri tauladan atau panutan yang baik bagi anaknya agar anak tumbuh dan berkembang menjadi pribadi yang baik dan berguna bagi bangsa. Selain orang tua, sekolah juga memiliki peran besar mencetak anak didik selain memiliki pengetahuan yang baik tetapi juga karakter yang baik pula, karena pendidikan disekolah tidak hanya bertujuan untuk memberikan pengetahuan kepada peserta didiknya tetapi juga pembentukan sikap dan perilaku. Semua ini bertujuan untuk membentuk anak dengan kepribadian yang baik sehingga mereka senantiasa dapat melakuakan perbuatan yang baik dan tidak meresahkan masyarakat. 


\section{DAPTAR PUSTAKA}

Azwar, A. 2000. Kesehatan Reproduksi Remaja di Indonesia (Adolescent Reproductive Health in Indonesia) Bali Post. 18 April 2014. http:// www.Balipost,com

Antara News. 2011. Mendiknas: Penerapan Pendidikan Karakter Dimulai SD, (Online). (http: //www.antaranews.com, diakses 10 pebruari 2016).

Asiyah, Ririn Nur. 1996. Upaya Penanggulangan Kenakalan Remaja SMUN di Kabupaten Boyolali. Malang: Jurusan Pendidikan Pancasila dan Kewarga-negaraan FIP IKIP MALANG

BKKBN. 2010. Penyiapan Kehidupan Berkeluarga Bagi Remaja. Direktorat Remaja dan Perlindungan Hak-hak Reproduksi. Jakarta

Gunarsa, Singgih D. Dan Gunarsa Y., Singgih D. 1986. Psikologi Perkembangan Anak dan Remaja. Jakarta: BPK Gunung Mulia.

Husaini, Akhmad. (2013). Peran Orang Tua Dalam Mendidik Anak. Diunduh di (http://edukasi.kompasiana.com/2013/10/ 07/peran-orangtua-dalam-mendidik anak596469.html), 5 pebruari 2016.

Jurjis, Malak. (2004). Cara Mengatasi Gejolak Emosi anak. Jakarta Selatan: Hikmah
Kertajaya Hermawan, 2010. Diferensiasi. Jakarta, Gramedia

Lickona Thomas. 2004. Educating for Character: How Our Schools Can Teach Respect and Responsibility (dalam Nuraini Farida, 2014. Sunan Kalijaga Yogyakarta

Majid Abdul dan Andayani Dian. ( 2011). Pendidikan Karakter : perspektif Islam.Bandung: PT. Remaja Rosdakarya

Prasetyo, A., dan Rivasintha, E. 2010. Konsep, Urgensi, dan Implementasi Pendidikan Karakter di Sekolah, (Online). (http:// edukasi. kompasiana.com, diakses 10 Pebruarii 2016

Susanti, Dwi. 2007. Hubungan Persepsi dan Sikap Siswa Terhadap Kenakalan

Remaja di SMA Negeri Gondang Tulungagung. Malang: Program Studi Bimbingan dan Konseling FIP UM

Suyanto Slamet. 2009. Pendidikan Karakter Melalui Pembelajaran Terpadu. Yogyakarta

Soedarsono. 2004. Kenakalan Remaja. Jakarta: Rineka Cipta

Willis, Sofyan S. 2005. Remaja dan Masalahnya: Mengupas Berbagai Bentuk Kenakalan Remaja, Seperti Narkoba, Free Sex dan Pencegahannya. Bandung: Alfabeta. 